\title{
Overtourism. It's time for some answers
}

Like a volcano, overtourism has been threatening to erupt for a very long time. Many decades ago, academics recorded the first grumblings to identify concerns about the structures of tourism.

More recently, residents across the world began to see dark smoke and to raise serious concerns while ecologists started to wonder if tourism was at risk of overwhelming parts of our natural world.

Three years ago overtourism volcanoes erupted all over the world and the issues associated with the industry's unmanaged and unsustainable growth were thrust into the media and the public spotlight. A subject mostly confined to academic papers and the classroom became front page news in The New York Times, Wall Street Journal and The South China Morning Post.

The sustainability of tourism became the first issue that industry leaders were asked about, rather than the last. Tourism ministers had to confront large scale protests from residents, street graffiti saying “tourist go home”, and tourists complaining of overcrowding.

Tourism essentially crossed a line, and not just in Venice and Barcelona where the protests were the loudest. Overtourism reports came in from every continent, from big cities to small island states and national parks.

While the straw that broke the camel's back in Venice might have been an extra few million tourists, even a few hundred or thousand had the same effect in smaller destinations with less capacity and little or no tourism management.

Historically the movement for more responsible and sustainable tourism has consisted of academics and activists, some progressive parts of the tourism industry (small and large) and a few enlightened destination managers.

Now local residents, and to a growing extent, tourists, are joining the fold. The late Jost Krippendorf, academic and author of The Holiday Makers, once said change in tourism will require "rebellious locals and rebellious tourists". Increasingly, the world has both.

Unlike the unavoidable rupture in the Earth's crust that causes volcanic eruptions, many of the issues in tourism that led to the current crisis could have been addressed.

One has to ask why they weren't, and to conclude that unmanaged growth suited an aggressive tourism industry and many destination managers whose misguided worldview was that everybody (residents, tourists, natural and cultural heritage) always benefit from tourism.

Reading industry and destination manager's responses to overtourism, it's hard not to conclude that many of them are totally unprepared to deal with the crisis on their doorstep. The challenge now is for all of us to work together to manage tourism better. 
This immensely readable book edited by Rachel Dodds and Richard W. Butler, hugely experienced and expert leaders in our field, provides much of what we will need. Always rooted in practical, destination-based examples, it neatly summarises the issues, the strategies we will need to address them, and - through a range of excellent case histories from contributors - many of the solutions to overtourism.

Whether you are a destination manager, work in the tourism industry, are a community leader, or a student of tourism, there will be something for you in this book.

We need all of you to help tourism to realise its potential to be a force for good. As its best it can bring together people of different colours, faiths, ages and income levels in joyful, caring and mutually beneficial ways that support development and the conservation of natural and cultural heritage. Never has the need for more responsible tourism been greater.

Justin Francis

Responsible Travel

Lewes, England, November 2018 